\title{
Review \\ Oral Manifestations in Children and Young Adults with Down Syndrome: A Systematic Review of the Literature
}

\author{
Maria Contaldo ${ }^{1,+}+\mathbb{D}$, Rossella Santoro ${ }^{1,+}{ }^{\dagger}$, Antonio Romano ${ }^{1}$, Francesca Loffredo ${ }^{1}$, Dario Di Stasio ${ }^{1}(\mathbb{D}$, \\ Fedora Della Vella ${ }^{2}{ }^{\mathbb{D}}$, Michele Scivetti ${ }^{3}$, Massimo Petruzzi ${ }^{2}{ }^{\mathbb{D}}$, Rosario Serpico ${ }^{1}$ and Alberta Lucchese ${ }^{1, *}$ \\ 1 Multidisciplinary Department of Medical-Surgical and Dental Specialties, University of Campania Luigi \\ Vanvitelli, Via Luigi de Crecchio 6, 80138 Naples, Italy; maria.contaldo@unicampania.it (M.C.); \\ rossella.santoro@unicampania.it (R.S.); antonio.romano4@unicampania.it (A.R.); \\ francescaloffredo1992@gmail.com (F.L.); dario.distasio@unicampania.it (D.D.S.); \\ rosario.serpico@unicampania.it (R.S.) \\ 2 Interdisciplinary Department of Medicine, University of Bari “Aldo Moro", 70121 Bari, Italy; \\ dellavellaf@gmail.com (F.D.V.); massimo.petruzzi@uniba.it (M.P.) \\ 3 Private Practice, Studio Odontoiatrico Dr. Scivetti, Via Bovio 49, Giovinazzo, 70054 Bari, Italy; \\ info@studioscivetti.it \\ * Correspondence: alberta.lucchese@unicampania.it; Tel.: +39-081-5667-670 \\ + These authors contributed equally to this work as co-first authors.
}

check for updates

Citation: Contaldo, M.; Santoro, R.; Romano, A.; Loffredo, F.; Di Stasio,

D.; Della Vella, F.; Scivetti, M.;

Petruzzi, M.; Serpico, R.; Lucchese, A Oral Manifestations in Children and Young Adults with Down Syndrome: A Systematic Review of the Literature Appl. Sci. 2021, 11, 5408. https:// doi.org/10.3390/app11125408

Academic Editor: Gaspare Palaia

Received: 18 May 2021

Accepted: 7 June 2021

Published: 10 June 2021

Publisher's Note: MDPI stays neutral with regard to jurisdictional claims in published maps and institutional affiliations.

Copyright: (c) 2021 by the authors. Licensee MDPI, Basel, Switzerland. This article is an open access article distributed under the terms and conditions of the Creative Commons Attribution (CC BY) license (https:// creativecommons.org/licenses/by/ $4.0 /)$.
Featured Application: The identification of the oral mucosa findings and oral candidiasis in children/young adults with Down Syndrome could help paediatricians, dentists, and parents/caregivers to manage them in the more appropriate way.

Abstract: Down syndrome (DS) is an autosomal disorder associated with mental and physical involvement. The typical craniofacial phenotype and the dental anomalies in DS subjects have been widely described, but a systematic report on the manifestations affecting the oral mucosae in children with DS is still lacking. This systematic review aimed to establish the prevalence of oral mucosal manifestations in children/young adults with DS. Pubmed, Web of Science, and Scopus were investigated in September 2020. Documents in English on DS children/young adults (up to 25 years) reporting oral mucosal findings were considered. Study quality was assessed with ROBIN-I. Of the 150 references retrieved, 14 studies were considered eligible. The risk of bias ranged from low to unclear. Fissured tongue appeared to increase with age and was more prevalent in DS children than in the general population. Lip fissures and cheilitis were heterogeneously reported. Candida spp. carriage with and without active candidiasis was more frequent in DS children/young adults than in controls. C. albicans was the most prevalent species. Few other oral mucosal conditions have been reported sporadically. The heterogeneity of the works revealed the need for more appropriate oral examination to intercept the oral manifestations of oral mucosa and prevent recurrent candidiasis.

Keywords: down syndrome; children; oral mucosa; geographic tongue; glossitis; candidiasis; cheilitis

\section{Introduction}

Down syndrome (DS) is an autosomal congenital disorder caused by the presence of all or part of an extra 21st chromosome. DS is also called Trisomy 21, 95\% of cases being caused by a numerical change of chromosome 21, with an extra copy that creates a chromosome count of 47; less frequently, DS is a consequence of the translocation of part of an extra chromosome 21 (3-4\% of cases), or mosaicisms (1-2\% of cases) [1]. DS is the most common trisomy compatible with life; its incidence is influenced by maternal age and ranges from 1 in 319 to 1000 live births worldwide [2].

Individuals with DS have mild to severe intellectual disability, growth retardation, and heart defects, and are more prone to be affected by hypertension, leukaemia, gastrointestinal problems, and early onset of Alzheimer's disease [2]. Among the typical 
and immediately recognizable oro-facial features, the most common are brachycephaly, epicanthic fold, slanted eyes, narrowed eye slits, cataracts and strabismus, flat nasal bridge, delayed dental eruption, dental agenesis, and small chin with microstomia and macroglossia, giving the typical phenotype of protruding tongue and lip incompetence [2]. The most common dermatological manifestations include alopecia areata, premature hair greying and ageing, palmoplantar hyperkeratosis, and xerosis [3].

The most reported manifestations of the oral mucosa are cheilitis, geographic tongue, and fissured tongue [4]; furthermore, people with DS are more prone to be affected by periodontal diseases and orofacial candidiasis, due to immunological disturbances and concomitant metabolic diseases such as diabetes [5].

Despite their common occurrence and various systematic reviews mainly focusing on craniofacial and/or dental anomalies in DS in subjects of all ages [6], a detailed report on the peculiarity of the manifestations involving the oral mucosa in DS children has not yet been completed. Therefore, the present systematic review, performed by oral pathologists and paediatric dentists who interface with this type of affection every day, aimed to identify and synthesize the prevalence of oral manifestations of soft tissues in children and young adults with DS, to define future directions to support the practitioners involved in the care management of the DS children.

\section{Materials and Methods}

The present work was performed according to the Preferred Reporting Items for Systematic Reviews and Meta-Analysis (PRISMA) checklist [7]. The protocol was registered on PROSPERO (reference CRD42021224207) and the research query was formulated according to the PICOS method (Participants, Intervention, Comparison, Outcomes, and Study): the participants were children and young adults (age range 0-25 years) affected by Down syndrome (DS); the intervention was the examination of the oral mucosa; the comparison was towards subjects not affected by DS; the outcomes included the incidence/prevalence of oral mucosal manifestations; and the study design was a systematic review.

\subsection{Research Protocol}

The research was conducted on 17 September 2020, and the MesHs terms used and combined by Boolean connectors are reported in Table 1 .

Table 1. The MesHs terms used in the search and their combinations used Boolean connectors.

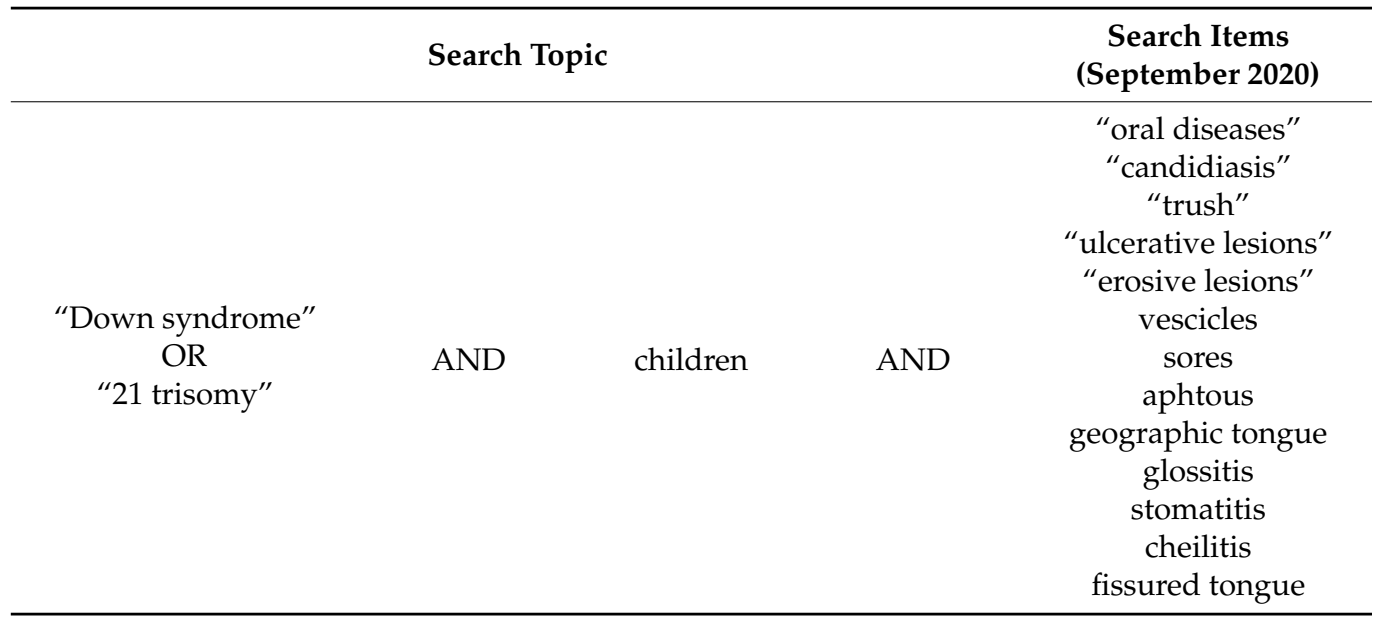




\subsection{Eligibility Criteria}

All original papers reported randomized controlled clinical trials and all observational studies (cohort and case-control studies, cross-sectional investigations, case series, and single case reports) describing oral mucosal manifestations in children with DS were included. Reviews, proceedings, letters, editorials, theses, abstracts, and all studies written in a language other than English were not taken into consideration.

Studies involving subjects over 25 years of age or children with no DS or no manifestations at the oral mucosa were excluded, while those reporting stratified age groups from which data related to paediatric/young adult population could be extracted were considered just for the latter, as well studies that reported alterations of soft and hard tissues, in which only the former were considered.

\subsection{Literature Search, Selection of Studies and Data Extraction}

Pubmed, Web of Science (WoS), and Scopus were investigated with no limits of year of publishing, from the first available date until September 2020. The results of the three searches were imported and combined with Mendeley-Reference Management Software \& Researcher Network (available at https:/ / www.mendeley.com (access on 20 January 2021). After the duplicates were removed, two reviewers examined the titles and abstracts from the documents and excluded any papers that did not meet the inclusion criteria. If the abstract did not provide sufficient information to evaluate the eligibility of the paper, its full text was considered. Then, two reviewers thoroughly read the full texts of the remaining articles to assess the relevance of the content of each study and consider those suitable for qualitative synthesis. In both steps, a third author was consulted in cases of disagreement between the two reviewers.

Full texts of the studies deemed suitable for inclusion were obtained and the following data extracted from each work: type of study, sample size, age range and sex of the subjects, and oral mucosal manifestations reported in children with DS.

\subsection{Risk of Bias (RoB) in Individual Studies}

Every single study was independently evaluated by two authors (and by a third in case of disagreement between them) to assess the risk of bias (RoB), following the seven domains-based assessment described by Sterne et al. in the Risk of Bias in NonRandomised Studies of Interventions (ROBINS-I) [8]: bias due to confounding, selection of participants, classification of interventions, deviations from intended interventions, missing data, measurement of outcomes, and selection of the reported results.

Using the ROBIN-I tool, each study was overall classified as follows: "low risk of bias"(LR) if all criteria were met and the study was comparable to a well-performed randomized trial; "moderate risk of bias" (MR) when the study appeared to be nonrandomized study but could be considered comparable to a well-performed randomized trial; "serious risk of bias" (SR) if one or more criteria have not been met and one or more plausible bias have severely undermined confidence in the results; "critical risk of bias" (CR) for studies too problematic and reporting critical bias; and "unclear risk of bias" (UR) if one or more criteria were rated as unclear and/or a plausible bias raised some doubts about the results.

\section{Results}

In total, 223 articles were identified (Figure 1). After 73 duplicates were removed, the remaining 150 articles underwent the first selection based on inclusion/exclusion criteria and title/abstract. After screening for relevance, 128 articles were excluded, and the remaining 22 papers underwent full-text assessment for eligibility. At the end of this selection, 14 original papers were included for fulfilling the requirements and were analyzed for qualitative review (Table 2). 


\subsection{Characteristics of the Studies}

An overview of the main characteristics retrieved from the 14 studies is shown in Table 2. Among the 14 studies considered, published in English between 1996 and 2020, two were performed in Turkey [9,10], one in Sweden [11], one in China [12], two in Spain [13,14] (one of which took place partly also in UK [13]), two in Brazil [15,16], one in Iran [3], two in India [17,18], one in Portugal [19], one in Yemen [20], and one in Poland [21]. In nine studies $[3,9-12,14,15,19,20]$ the age range of all participants fell within the range considered (0-25 years) and in the remaining five studies $[12,16-18,21]$ only data referring to subjects under the age of 25 were considered. Aside from one case report by Chow et al. [12], the remaining 13 studies were observational: six case-control studies on DS subjects and agedand sex-matched healthy subjects $[9-11,15,16,19]$, and seven cohort studies on subjects with DS $[3,13,14,17,18,20,21]$.

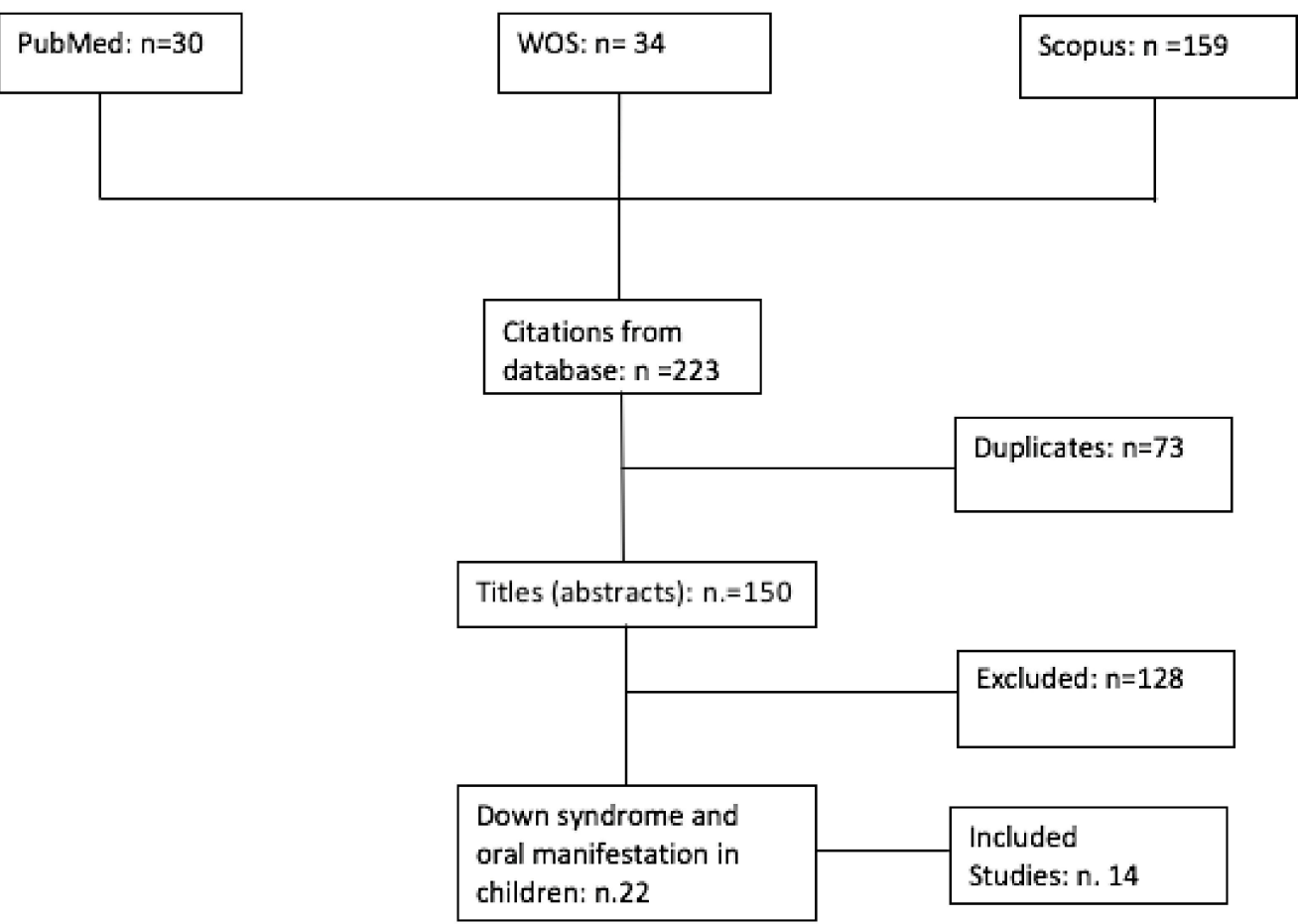

Figure 1. Flowchart summarizing the selection process. 
Table 2. Main characteristics of the works included.

\begin{tabular}{|c|c|c|c|c|c|c|c|c|c|c|c|c|c|}
\hline & $\begin{array}{c}\text { First } \\
\text { Author, Year, } \\
\text { Country }\end{array}$ & $\begin{array}{l}\text { Type of } \\
\text { Study }\end{array}$ & Outcome & DS Diagnosis & $\begin{array}{l}\text { N. of } \\
\text { Patients } \\
\text { Enrolled } \\
\text { with DS }\end{array}$ & $\begin{array}{l}\text { Mean Age } \\
\text { (Range) Yr }\end{array}$ & Sex F:M (\%) & $\begin{array}{c}\text { Experts } \\
\text { Performing } \\
\text { the Oral } \\
\text { Examinations }\end{array}$ & $\begin{array}{l}\text { Fissured } \\
\text { Tongue }\end{array}$ & $\begin{array}{c}\text { Geographic } \\
\text { Tongue }\end{array}$ & $\begin{array}{l}\text { Other } \\
\text { Lingual/Oral } \\
\text { Affections }\end{array}$ & $\begin{array}{l}\text { Lip } \\
\text { Fissures, } \\
\text { Cheilitiis }\end{array}$ & $\begin{array}{c}\text { Oral } \\
\text { Candidiadis/ } \\
\text { Candida spp. } \\
\text { Carriage }\end{array}$ \\
\hline 1 & $\begin{array}{c}\text { Ercis et al. (1996) } \\
\text { [9], Turkey }\end{array}$ & cohort & $\begin{array}{l}\text { mucocutaneous } \\
\text { findings in DS } \\
\text { children }\end{array}$ & $\begin{array}{c}\text { partly clinical, } \\
\text { partly } \\
\text { chromosomal }^{\#}\end{array}$ & 71 & $2.83(0.17-25)$ & $\begin{array}{c}30: 41 \\
(42 \%: 58 \%)\end{array}$ & dermatologists & yes & yes & & yes & \\
\hline 2 & $\begin{array}{l}\text { Carlstedt et al. } \\
\text { (1996) [11], } \\
\text { Sweden }\end{array}$ & case-control & $\begin{array}{l}\text { Oral carriage of } \\
\text { Candida species } \\
\text { in DS children } \\
\text { and adolescents }\end{array}$ & not specified & 55 & $\begin{array}{l}6.7 \pm 5.3 \\
(0.6-20.5)\end{array}$ & $\begin{array}{c}21: 34 \\
(38 \%: 62 \%)\end{array}$ & dentist & & & & & yes \\
\hline 3 & $\begin{array}{l}\text { Chow et al. (1997) } \\
\text { [12], China }\end{array}$ & $\begin{array}{l}\text { case } \\
\text { report }\end{array}$ & $\begin{array}{l}\text { dental and oral } \\
\text { anomalies in one } \\
\text { DS girl }\end{array}$ & not specified & 1 & 12.5 & 1:0 & dentist & yes & & & & \\
\hline 4 & $\begin{array}{l}\text { Scully et al. (2002) } \\
\text { [13], UK/Spain }\end{array}$ & cohort & $\begin{array}{c}\text { lip lesions } \\
\text { and C.albicans in } \\
\text { DS children and } \\
\text { adults }\end{array}$ & chromosomal & $\begin{array}{c}77 \\
\text { (39 under } 30 \\
\text { yr) }\end{array}$ & $(0->60)$ & $37: 40$ & dentist & & & & yes & yes \\
\hline 5 & $\begin{array}{l}\text { Ribeiro et al. } \\
\text { (2006) [15], Brazil }\end{array}$ & case-control & $\begin{array}{c}\text { C.albicans } \\
\text { phenotype in DS } \\
\text { children }\end{array}$ & chromosomal & 25 & $(0-10)$ & & dentist & & & & yes & yes \\
\hline 6 & $\begin{array}{l}\text { Daneshpazhooh } \\
\text { et al. (2007) [3], } \\
\text { Iran }\end{array}$ & cohort & $\begin{array}{l}\text { mucocutaneous } \\
\text { findings in DS } \\
\text { children }\end{array}$ & not specified & 100 & $\begin{array}{c}11.2 \\
(3-20)\end{array}$ & $53: 47$ & dermatologist & yes & yes & $\begin{array}{l}\text { hypertrophy } \\
\text { of tongue } \\
\text { papilla }\end{array}$ & yes & \\
\hline 7 & $\begin{array}{l}\text { Bilgili et al. (2011) } \\
\text { [10], Turkey }\end{array}$ & case-control & $\begin{array}{l}\text { mucocutaneous } \\
\text { findings in DS } \\
\text { children and } \\
\text { healthy controls }\end{array}$ & $\begin{array}{c}\text { partrly clinical, } \\
\text { partly } \\
\text { chromosomal }\end{array}$ & 50 & $\begin{array}{c}1.08 \\
(0-11)\end{array}$ & $\begin{array}{c}22: 28 \\
(44 \%: 56 \%)\end{array}$ & dermatologists & yes & yes & & yes & \\
\hline 8 & $\begin{array}{l}\text { Sureshbabu et al. } \\
\text { (2011) [17], India }\end{array}$ & cohort & $\begin{array}{l}\text { mucocutaneous } \\
\text { findings in DS } \\
\text { children }\end{array}$ & chromosomal & $\begin{array}{c}95(67 \text { up to } \\
14 \text { yr, } 28 \mathrm{more} \\
\text { than } 14 \mathrm{yr}\end{array}$ & $\begin{array}{c}11.97 \pm 8.8 \\
(0.5-40)\end{array}$ & $59: 36$ & $\begin{array}{c}\text { dermatologist } \\
\text { and } \\
\text { paediatrician }\end{array}$ & yes & & & yes & yes \\
\hline 9 & $\begin{array}{l}\text { Arejas et al. (2012) } \\
\text { [19], Portugal }\end{array}$ & case/control & $\begin{array}{c}\text { mutans } \\
\text { streptococci, } \\
\text { lactobacilli and } \\
\text { Candida } \\
\text { relative } \\
\text { frequencies in } \\
\text { saliva samples } \\
\text { from DS children } \\
\text { and controls }\end{array}$ & not specified & 45 & $\begin{array}{c}12.7 \pm 4.0 \\
(6-18)\end{array}$ & $\begin{array}{c}23: 22 \\
(51 \%: 49 \%)\end{array}$ & dentists & & & & & Yes \\
\hline
\end{tabular}


Table 2. Cont.

\begin{tabular}{|c|c|c|c|c|c|c|c|c|c|c|c|c|c|}
\hline & $\begin{array}{c}\text { First } \\
\text { Author, Year, } \\
\text { Country }\end{array}$ & $\begin{array}{l}\text { Type of } \\
\text { Study }\end{array}$ & Outcome & DS Diagnosis & $\begin{array}{c}\text { N. of } \\
\text { Patients } \\
\text { Enrolled } \\
\text { with DS }\end{array}$ & $\begin{array}{l}\text { Mean Age } \\
\text { (Range) Yr }\end{array}$ & Sex F:M (\%) & $\begin{array}{c}\text { Experts } \\
\text { Performing } \\
\text { the Oral } \\
\text { Examinations }\end{array}$ & $\begin{array}{c}\text { Fissured } \\
\text { Tongue }\end{array}$ & $\begin{array}{c}\text { Geographic } \\
\text { Tongue }\end{array}$ & $\begin{array}{c}\text { Other } \\
\text { Lingual/Oral } \\
\text { Affections }\end{array}$ & $\begin{array}{c}\text { Lip } \\
\text { Fissures, } \\
\text { Cheilitiis }\end{array}$ & $\begin{array}{c}\text { Oral } \\
\text { Candidiadis/ } \\
\text { Candida spp. } \\
\text { Carriage }\end{array}$ \\
\hline \multirow[b]{2}{*}{10} & \multirow{2}{*}{$\begin{array}{l}\text { Camacho et al. } \\
\text { (2014) [14], Spain }\end{array}$} & \multirow[b]{2}{*}{ cohort } & $\begin{array}{l}\text { mucocutaneous } \\
\text { findings in DS } \\
\text { children and } \\
\text { young adults }\end{array}$ & not specified & 57 & $\begin{array}{l}16.7 \\
(2-29)\end{array}$ & $\begin{array}{c}23: 34 \\
(39 \%: 61 \%)\end{array}$ & \multirow{2}{*}{ dermatologists } & yes & & & yes & \\
\hline & & & $\begin{array}{l}\text { mucocutaneous } \\
\text { findings in } \\
\text { children with } \\
\text { alopecia aerata } \\
\text { and DS }\end{array}$ & not specified & 15 & $\begin{array}{l}11.2 \\
(7-16)\end{array}$ & 7:8 (47\%:53\%) & & yes & & & yes & \\
\hline 11 & $\begin{array}{l}\text { Shukla et al. } \\
\text { (2014) [18], India }\end{array}$ & cohort & $\begin{array}{c}\text { dentofacial } \\
\text { abnormalities in } \\
\text { DS children and } \\
\text { young adults }\end{array}$ & not specified & 77 & $(6-40)$ & 7:70 (9\%:91\%) & dentists & yes & & $\begin{array}{l}\text { macroglossia, } \\
\text { ankyloglossia }\end{array}$ & yes & \\
\hline 12 & $\begin{array}{l}\text { Al-Maweri et al. } \\
\text { (2015) [20], Yemen }\end{array}$ & cohort & $\begin{array}{l}\text { Lip and oral } \\
\text { lesions in DS } \\
\text { children }\end{array}$ & karyotyping & 50 & $\begin{array}{l}12.66 \\
(6-18)\end{array}$ & $\begin{array}{c}19: 31 \\
(38 \%: 62 \%)\end{array}$ & dentists & yes & & $\begin{array}{l}\text { herpes } \\
\text { labialis, } \\
\text { fibroma, } \\
\text { traumatic } \\
\text { ulcers }\end{array}$ & yes & \\
\hline 13 & $\begin{array}{c}\text { Szaflarska- } \\
\text { Popławska et al. } \\
\text { (2016) [21], Poland }\end{array}$ & cohort & $\begin{array}{c}\text { Aphthous } \\
\text { stomatitis and } \\
\text { enamel } \\
\text { hypoplasia in DS } \\
\text { children and } \\
\text { young adult with } \\
\text { and without } \\
\text { coeliac disease }\end{array}$ & Genetic * & 301 & $(1-34)$ & $\begin{array}{c}137: 164 \\
(45.5 \%: 54.5 \%)\end{array}$ & pediatricians & & & $\begin{array}{l}\text { aphthous } \\
\text { stomatitis }\end{array}$ & & \\
\hline 14 & $\begin{array}{l}\text { Maranhão et al. } \\
\text { (2020) [16], Brazil }\end{array}$ & case-control & $\begin{array}{c}\text { Molecular } \\
\text { Identification of } \\
\text { Candida Species } \\
\text { in the Oral } \\
\text { Microbiota of Ds } \\
\text { children and } \\
\text { young adults }\end{array}$ & not specified & 80 & $12.8(0.5-34)$ & $31: 49$ & geneticists & & & & & yes \\
\hline
\end{tabular}

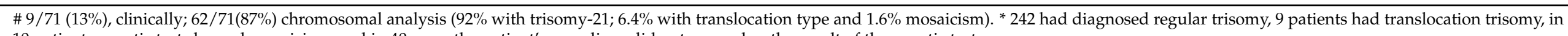
10 patients genetic test showed mosaicism, and in 40 cases the patient's guardians did not remember the result of the genetic test. 


\subsection{Risk of Bias (RoB) Assessment}

When assessed with ROBINS-I, (Table 3), three studies were graded as SR $[16,18,19]$ and eleven as MR $[3,9-15,17,20,21]$. In details, being the DS phenotypically recognizable, no blinding observation was possible, and therefore the biases due to departures from intended interventions were all at moderate risk, while the biases due to confounding were always uninterpretable (UR). Regarding selection bias, one study [12] was a case report, and were therefore considered MR, three studies recruited only volunteers and were therefore considered SR $[16,18,19]$, five studies that enrolled consecutive/random patients presented as $\operatorname{LR}[9,11,17,20,21]$, and in the remaining five studies $[3,10,13-15]$ the recruitment selection was not clearly reported. The biases due to the missing data were related to the partial lack of stratification of the results according to the age groups considered, thus not allowing only the age groups of the inclusion criteria for those studies classified as MR to be considered. The biases in measurement outcomes were related to the examination performed by the same examiners (LR) or more than one (MR).

Table 3. Risk of bias assessment for individual studies.

\begin{tabular}{|c|c|c|c|c|c|c|c|c|}
\hline Observational Studies & $\begin{array}{l}\text { Bias Due to } \\
\text { Confounding }\end{array}$ & $\begin{array}{c}\text { Bias in } \\
\text { Participant } \\
\text { Selection }\end{array}$ & $\begin{array}{c}\text { Bias in } \\
\text { Classification of } \\
\text { Interventions }\end{array}$ & $\begin{array}{l}\text { Bias Due to } \\
\text { Departures } \\
\text { from } \\
\text { Intended } \\
\text { Interventions }\end{array}$ & $\begin{array}{l}\text { Bias Due to } \\
\text { Missing } \\
\text { Data }\end{array}$ & $\begin{array}{l}\text { Bias in } \\
\text { Measurement } \\
\text { of Outcomes }\end{array}$ & $\begin{array}{c}\text { Bias in } \\
\text { Selection of } \\
\text { the Reported } \\
\text { Result }\end{array}$ & $\begin{array}{c}\text { Overall } \\
\text { Bias }\end{array}$ \\
\hline Ercis et al. [9] & UR & LR & MR & MR & MR & LR & LR & MR \\
\hline Carlstedt et al. [11] & UR & LR & LR & MR & LR & LR & LR & MR \\
\hline Chow et al. [12] & UR & MR & MR & MR & LR & LR & SR & MR \\
\hline Scully et al. [13] & UR & UR & LR & MR & MR & LR & LR & MR \\
\hline Ribeiro et al. [15] & UR & UR & LR & MR & LR & LR & LR & MR \\
\hline Daneshpazhooh et al. [3] & UR & UR & MR & MR & LR & LR & LR & MR \\
\hline Bilgili et al. [10] & UR & UR & MR & MR & LR & LR & LR & MR \\
\hline Sureshbabu et al. [17] & UR & LR & MR & MR & LR & LR & LR & MR \\
\hline Arejas et al. [19] & UR & SR & LR & MR & LR & LR & LR & SR \\
\hline Camacho et al. [14] & UR & UR & MR & MR & MR & LR & LR & MR \\
\hline Shukla et al. [18] & UR & SR & LR & MR & MR & LR & LR & SR \\
\hline Al-Maweri et al. [20] & UR & LR & LR & MR & MR & LR & LR & MR \\
\hline $\begin{array}{c}\text { Szaflarska-Popławska } \\
\text { et al. [21] }\end{array}$ & UR & LR & MR & MR & LR & $\mathrm{LR}$ & LR & MR \\
\hline Maranhão et al. [16] & UR & SR & SR & MR & MR & MR & LR & SR \\
\hline
\end{tabular}

The Risk of Bias in non-randomized studies—of interventions (ROBINS-I) tool was used for observational studies. Each domain was classified as low risk (LR), moderate risk (MR), serious risk (SR), and critical risk (CR), or not interpretable (UR). An overall bias assessment was then made using the same scale.

\subsection{Outcome}

Oral examination was performed by oral pathologists and/or dental practitioners in seven works, while in the remaining works it was performed by dermatologists, geneticists, and/or paediatricians. Fissured tongue and lip lesions/cheilitis were the most frequently reported and investigated oral mucosal findings, described in eight $[3,9,10,12,14,17,18,20]$ and nine $[3,9,10,13-15,17,18,20]$ studies, respectively; the geographic tongue was reported in three studies $[3,9,10]$ and other lingual and/oral affections were variously reported in four studies $[3,18,20,21]$; five studies focused on oral candidiasis and/or Candida spp. carriage in children with DS $[11,13,15,17,19]$.

\subsubsection{Fissured Tongue}

Fissured tongue (FT) is a benign, usually asymptomatic condition characterized by deep grooves on the dorsal surface and margins of the tongue [22]. Eight works investigated the prevalence of FT in groups of children with DS (Table 4): one case report [12], six cohort studies $[3,9,14,17,18,20]$, and one age- and sex-matched case/control study [10]. The grouping by age of the subjects was heterogeneous among studies and details for each work have been summarized in Table 4, in the legend. 
Table 4. Fissured tongue: characteristics of the eight works investigating the prevalence of FT in children with DS, by age groups.

\begin{tabular}{|c|c|c|c|c|c|c|c|c|}
\hline & \multirow{2}{*}{$\begin{array}{l}\text { Mean Age } \\
\text { (Range) Yr }\end{array}$} & \multicolumn{7}{|c|}{ Fissured Tongue } \\
\hline & & $0-1$ Years & 1-2 Years & 2-5 Years & 5-10 Years & 10-15 Years & $>15$ Years & Total \\
\hline Ercis et al. [9] & $2.83(0.17-25)$ & $1 / 28(6 \%)$ & $0 / 16(0 \%)$ & $5 / 15(33 \%)$ & \multicolumn{3}{|c|}{$9 / 12(75 \%)$} & $15 / 71(21 \%)$ \\
\hline Chow et al. [12] & 12.5 & \multicolumn{4}{|c|}{ n.c. } & $1 / 1(100 \%)$ & n.c. & $1 / 1(100 \%)$ \\
\hline Daneshpazhooh et al. [3] & $11.2(3-20)$ & & $0 / 8(0 \%)$ & & $7 / 33(21 \%)$ & $17 / 50(34 \%)$ & $4 / 9(44 \%)$ & $28 / 100(28 \%)$ \\
\hline Bilgili et al. [10] & $1.08(0-11)$ & \multicolumn{4}{|c|}{$5 / 50(10 \%)$} & \multicolumn{2}{|c|}{ n.c. } & $5 / 50(10 \%)$ \\
\hline Sureshbabu et al. [17] & $\begin{array}{c}11.97 \pm 8.8 \\
(0.5-40)\end{array}$ & \multirow{2}{*}{\multicolumn{6}{|c|}{$35 / 67(52 \%)$}} & $50 / 95(53 \%)$ \\
\hline \multirow{2}{*}{ Comacho et al. [14] $\$$} & $16.7(2-29)$ & & & & & & & $44 / 72\left(61^{\circ}\right)$ \\
\hline & $11.2(7-16)$ & \multicolumn{3}{|c|}{ n.c. } & \multicolumn{2}{|c|}{$4 / 15(27 \%)$} & n.c. & $44 / 72(61 \%)$ \\
\hline Shukla et al. [18] ${ }^{\#}$ & $(6-40)$ & \multicolumn{6}{|c|}{$39 / 50(78 \%)$} & $52 / 77(68 \%)$ \\
\hline Al-Maweri et al. [20] & $12.66(6-18)$ & \multicolumn{3}{|c|}{ n.c. } & $7 / 9(78 \%)$ & $14 / 21(67 \%)$ & $18 / 20(90 \%)$ & $39 / 50(78 \%)$ \\
\hline
\end{tabular}

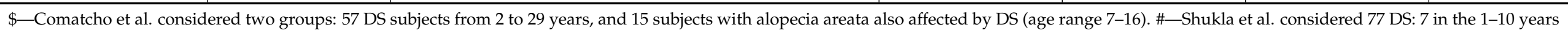

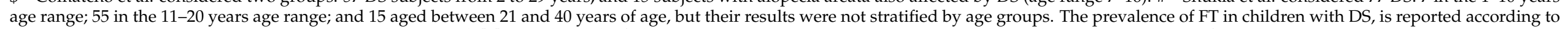

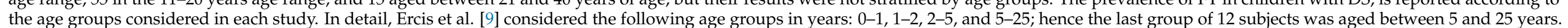

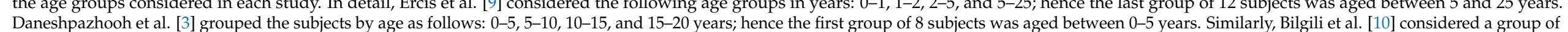

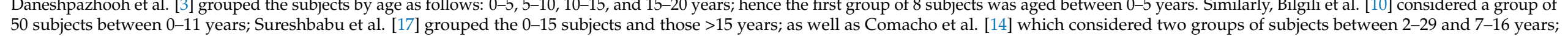
Shukla et al. [18] did not consider results by age groups and Al-Maweri et al. [20] considered the following age groups: 5-10, 10-15, and 15-18 years. n.c.-“age groups not considered in the study" 
The prevalence of FT increased with age. In DS children aged 0-5 years, Ercis et al. [9] reported $10 \%$ in a total of 59 subjects, while Daneshpazhooh et al. [3] found no FT in the 8 DS children considered in their study. In children with DS aged 5-10 years, Daneshpazhooh et al. [3] found FT in 21\% of 33 subjects and Al-Maweri et al. [20] reported a prevalence of $78 \%$ of 9 subjects. In DS subjects between 10 and 15 years of age, FT varied from $34 \%$ of 50 subjects analyzed by Daneshpazhooh et al. [3] to 67\% in 21 children by Al-Maweri et al. [20], up to 75\% on 12 children reported by Ercis et al. [9]. Chow et al. [12] reported a case of a 12-old girl with FT.

Regarding DS subjects over the age of 15, only the data from Daneshpazhooh et al. [3] and Al-Maweri et al. [20] could be considered, the maximum age of the subjects enrolled being within 20 [3] and 18 years [20], with the prevalence of FT of $44 \%$ and $90 \%$, respectively. Bilgili et al. [10] reported a higher statistical prevalence of FT in 50 children of the DS group compared to 50 healthy controls $(10 \%$ versus $0 \%, p$-value $=0.018$, age range $0-11$ years).

\subsubsection{Geographic Tongue}

Geographic tongue (GT) was reported in two cohort studies [3,9] and one case-control study [10]. GT is a benign condition of uncertain aetiology affecting the dorsal tongue, its margins and, rarely, other oral sites [22]. The percentages of GT reported were: 11\% of 71 DS subjects (age range $0.17-25$ years) by Ercis et al. [9]; 4\% out of 100 DS subjects (age range 3-20 years) by Daneshpazhooh et al. [3]; and 2\% out of 50 DS subjects by Bilgili et al. [10] (age range $0-11$ years). When data were stratified by age groups, Ercis et al. found GT in 8 out of 59 subjects (14\%) in the $0-5$ years age group and no cases were reported in the 12 remaining subjects 6-25 years of age. In contrast, Daneshpazhooh et al. found no cases of GT in the eight children 0-5 years and 4 cases out of 92 in the subjects 6-25 years (4\%). Bilgili et al. [10] reported no statistically significant differences in the GT prevalence between the DS group and the healthy controls.

\subsubsection{Lip Lesions (Lip Fissures and Cheilitis)}

Eight papers reported various types of lip affections $[3,9,10,13,14,17,18,20]$, mainly cheilitis and lip fissures (Table 5). The origin of cheilitis has not always been reported or associated with fungal/bacterial infections. The nonspecific definition of "cheilitis" was reported in five studies, and the one by Sureshbabu et al. [17] distinguished between "cheilitis" and "angular cheilitis". As for FT, also in this case the studies have considered different age grouping and the details for each work have been summarized in Table 5, in legend. In the studies reporting lip lesions both in children than in adults over 25 years old, only the first ones have been considered.

Angular cheilitis was reported in 7\% of 67 subjects by Sureshbabu et al. [17] and $73 \%$ of 15 subjects by Camacho et al. [14]: both works reported these rates in children aged 0-15 years. Shukla et al. [18] and Scully et al. [13] considered age groups between $0-40$ and $0->60$, respectively, and it was not possible to extrapolate age-stratified data: the overall prevalence in these two studies was $22 \%$ out of 77 subjects and $25 \%$ of 24 subjects, respectively.

In the studies investigating "cheilitis", it was lacking [3,17] or very low [9] in children with DS under the age of 5, while it increased in those aged 6 to 15 years. Scully et al. [13] considered an age range between $0-10$ years and the prevalence of cheilitis was $27 \%$ out of 11 subjects. In DS subjects older than 5 years, Ercis et al. [9] reported a prevalence of $25 \%$ of 12 subjects between 6-25 years, Daneshpazhooh et al. [3] 14\% of 92 subjects between 6-20 years, Sureshbabu et al. [17] reported $24 \%$ of 46 subjects aged 6-15, and Al-Maweri et al. [20] reported it in 14\% of 50 subjects aged 6-18 years. Bilgili et al. [10] reported a higher statistical prevalence of cheilitis in the DS groups aged 0 to 11 years compared to heathy controls $(6 \%$ versus $0 \%, p$ value $=0.009)$. 
Table 5. Lip lesions: characteristics of the eight works investigating the prevalence of lip lesions in children with DS, by age groups.

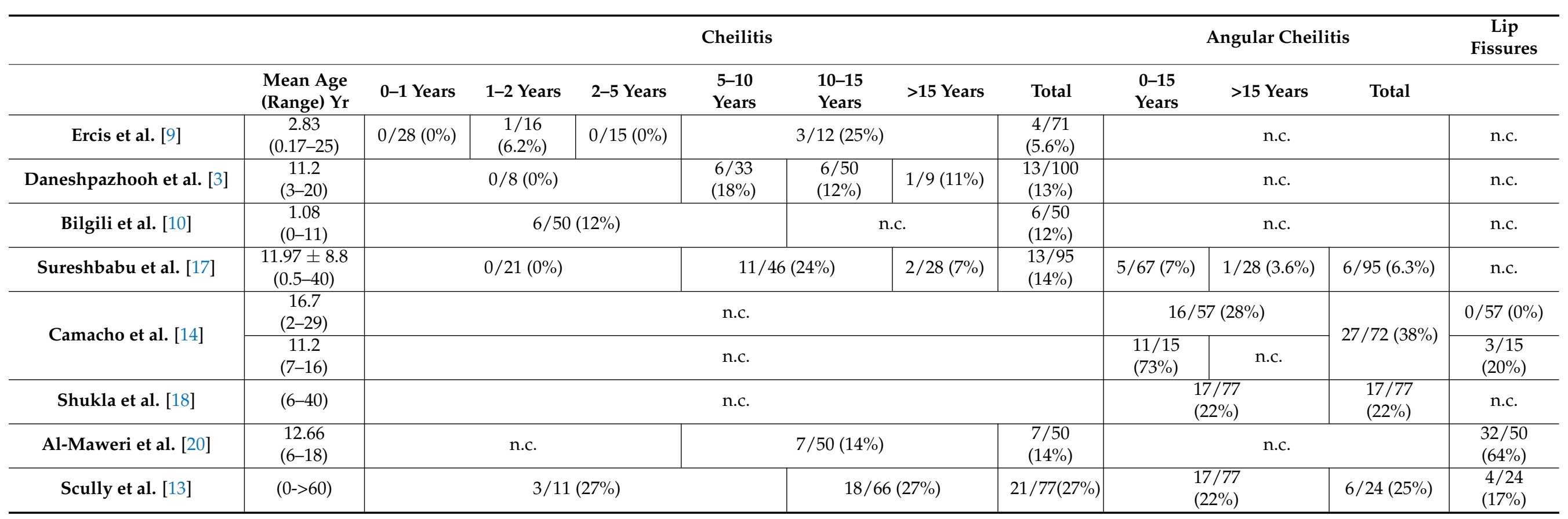

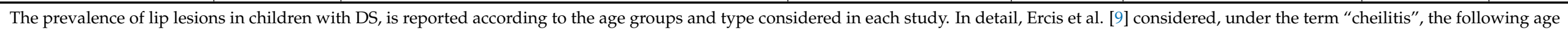

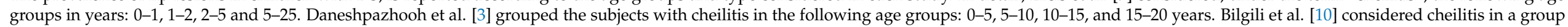

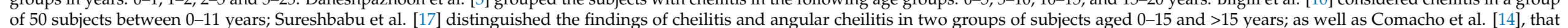

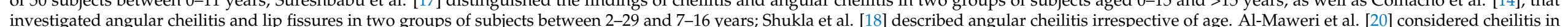

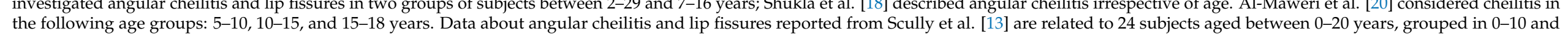
11-20 years, while, with regard to cheilitis, they considered 11 subjects $0-10$ years and 66 between 10 and $>60$ years, without any further age classification. n.c.- "not considered in the study". 
Lip fissures, also called cracked or fissured lips [13], have been reported in three papers $[13,14,20]$. Camacho et al. [14] found them in $20 \%$ of 15 DS subjects under the age of 16 and none in 57 other DS subjects aged between 2 and 29 years. Al-Maweri et al. [20] reported a rate of $64 \%$ in 50 subjects aged 6-18 years, while Scully et al. [13] reported a rate of $17 \%$ in 24 DS subjects aged $0-20$ years.

\subsubsection{Other Lingual/Oral Affections}

A few other findings of the oral mucosa have been sporadically reported: one case of herpes labialis, one of cheek biting and two traumatic ulcerations in 50 DS children considered by Al-Maweri et al. [20] and recurrent aphthous stomatitis not significantly different between DS children with and without the coeliac disease ( 15 vs. $11 \%$, respectively), reported by Szaflarska-Popławska et al. [21].

\subsubsection{Oral Candidiasis and Candida spp. Carriage}

Reports on Candida spp. carriage, species typing and associations with oral candidiasis in children with DS were extremely heterogeneous and, therefore, must be considered individually.

In 1996, Carlstedt et al. [11] reported oral carriage of Candida species in a case-control study enrolling 50 DS subjects aged 0.6-20.5 years and 50 age- and sex-matched healthy controls: in DS subjects, C. albicans colonization was significantly higher (69\% vs. 35\% of controls, $p$ value $<0.001)$ and significantly higher at tongue and palate as well as oral signs of erythematous candidiasis (40\% vs. $1.8 \%$ in healthy controls), while white pseudomembranous lesions did not statistically differ between groups. As for other Candida species, C. parapsilosis, C. guillermondii, and C. tropicalis were rarely found in both groups (0-1.8\%) and did not differ significantly.

In 2002, Scully et al. [13] evaluated the relationships between angular cheilitis, lip fissures, and C. albicans in a series of 50 DS subjects aged between 0-60 years and stratified by age. C. albicans was isolated in 11 of 13 subjects (84.6\%) aged $0-10$ years and in 7 of 12 $(58 \%)$ aged $11-20$ years. The presence of $C$. albicans was very frequently associated with lip lesions (in $80 \%$ of DS subjects aged $0-10$ years and in 100\% of those aged 11-20 years).

Four years later, Ribeiro et al. [15] conducted a case-control study on morphotyping and enzymotyping of C. albicans in 35 children aged $0-10$ years ( 25 with DS and 10 controls); results showed significantly higher levels of two fungal enzymes in DS compared to the control group, proteinase ( $96 \%$ in DS children vs. $40 \%$ ) and phospholipase ( $88 \%$ vs. $80 \%$ ).

In 2012, Areias et al. [19] published a case-control study to correlate relative frequencies of Streptococcus mutans, Lactobacilli, and Candida spp. in salivary samples from DS children and their healthy siblings closest in age. Although the work has focused on the synergistic effect of Candida spp. with Streptococci on the onset of caries, the work reported that the frequency of the Candida spp. carriage was higher in the control group than in the DS group, without reaching statistical significance, but according to the low caries rates reported in the DS subjects.

Camacho et al. [14] reported that C. albicans had been cultured twice frequently in those DS patients with lip lesions compared to those without lip lesions.

Recently, Maranhão et al. [16] identified Candida spp. in a case-control study on 80 DS (7.7 mean age) and 80 non-syndromic volunteers (12.8 mean age), finding a statistically significant higher percentage of Candida carriers among the case group than in the control group ( 57.5 vs. $12 \%$ ). Of these, C. albicans was the most prevalent species in both groups (93\% of the DS subjects and $60 \%$ of the controls); C. glabrata was found alone in $7 \%$ of DS children and associated with C. albicans in 35\% of them, while it was reported as the first and only species in $20 \%$ of controls. C. tropicalis and C. krusei were both found in $1 \%$ of controls as the only isolated species, while in DS subjects they were found as second species in association with C. albicans in 15\% (C. albicans + C. tropicalis) and $4 \%$ (C. albicans + C. $k$ rusei), respectively, but never alone. In the DS group, 49\% referred to previous oral candidiasis on questionnaires and $21 \%$ of them presented active candidiasis at the oral 
examination; the relative percentages in the control groups were $63 \%$ (history of oral candidiasis) and $0 \%$ (active oral candidiasis at examination), respectively.

\section{Discussion}

Various syndromic genetic disorders can be associated with oral manifestations, and, while some of them are extremely rare [23-27], many others are commonly seen: this is the case with Down syndrome (DS). DS is well known and its phenotypic aspect has been extensively described, but there is no systematic report on the particular prevalence of oral mucosal manifestation in children with DS.

Therefore, the present work systematically investigated the scientific literature to establish the conditions of the oral mucosa reported in children and young adults (from 0 to 25 years of age) with DS. Among the 150 papers found, only 14 fulfilled the inclusion criteria for the qualitative review.

The most reported findings were fissured tongue and lip lesions/cheilitis. Fissured tongue is a relatively common condition, more frequent in adulthood than in childhood, with a prevalence of approximately $2-5 \%$ of the general population, and ranging between $10-95 \%$ in DS, regardless of age [28].

In the studies considered here, although a precise stratification of prevalence percentages by years of age was not always reported, due to the different grouping systems adopted by the various authors, it was observed that the average prevalence of fissured tongue increases with age, being on average reported in 35\% of children between $0-15$ years (very rare before 2 years of age) and $65 \%$ of subjects over 15 years of age. The highest prevalence of FT was found by Sureshbabu et al. [17] in 52\% of 67 children younger than 15 years.

Geographic tongue (GT) is reported in 1-3\% of the healthy population, with no difference between females and males and ages [22]. Our results reported higher percentages of GT in DS children, being, in all studies considered, higher than the average prevalence in the population without Down syndrome. However, discordant trends were observed by age groups, as GT was reported higher (14\%) in 0-5 years of age compared to 6-25 years in one study [9] and the opposite by Daneshapazhooh et al. [3] (4\% of DS subjects between 6-20 years).

Cheilitis was reported in eight studies, but the definitions of sites and origins were homogeneous and not always considered. In particular, in the works in which the examination was performed by dentists and/or oral pathologists; these data were generally more defined than those reported by dermatologists or other medical specialists.

Oral candidiasis, Candida spp. typing and carriages have been the subject of various studies considered. Active oral candidiasis at clinical examination was more common in children/young adults with DS than in controls, as was the carrier status with no clinical signs of infection. Only the work by Areias et al. [19] has countered this finding, as they reported the frequency of the Candida spp. carriage was higher in the control group than in the DS, without reaching statistical significance. This could explain the lower caries rates in children with DS compared to healthy controls, but it does not endorse their greater susceptibility to oral candidiasis, thus imputing greater responsibility towards immunological disorders and/or oral lesions co-occurring in DS than the simple load of Candida spp. [29-31]. This hypothesis is reinforced by the evidence that $C$. albicans was the most prevalent species in both healthy subjects and DS ones, as well as it was found twice as frequently in those DS patients with lip lesions compared to those without lip lesions [13,20]; thus supporting the role of immunity, hyposalivation, and oral lesions in the onset of frequent oral infections in children with DS. Lastly, the work by Maranhão et al. [16] highlighted the coexistence of other Candida species (non-albicans Candida, NAC) besides C. albicans in DS compared with controls.

Only sporadic reports have been found regarding other oral mucosal conditions, such as herpes labialis, ulcerative/traumatic lesions, and check biting. 
Based on the reported results, it is possible to orient the practitioners dealing with DS children to the correct management of the manifestations affecting the oral mucosa of these subjects with special needs.

FT, being generally asymptomatic, usually does not require treatment. However, the furrows that characterize the fissured tongue can be a receptacle for food debris, bacterial plaque and fungi and, consequently, bad oral hygiene and infectious diseases may occur. To prevent the accumulation of dental plaque and/or the onset of fungal infections, it is recommended to educate parents and caregivers to perform the hygiene of the tongue of their DS child in addition to routine dental hygiene. For this purpose, the use of tongue scrapers and/or brush tongue cleaners can help to maintain acceptable levels of tongue hygiene.

When inflammation or mycosis have occurred, the treatment may consist of the removal of triggering factors and the use of topical and/or systemic antimycotic drugs.

While the usage of antifungal agents has been revised for the general pediatric population [32], literature about the antimycotic protocols specific for DS children is not yet reported. Pediatric subjects differ from adults in host biology, predisposing conditions and oral microbiome composition and the DS children are further different from the healthy ones, so that specific antifungal therapies are required. Hence, choosing the most appropriate antimycotic therapy in DS children is a serious challenge. The clinicians dealing with oral candidiasis in these subjects must consider the general health conditions of each subject, the presence of immunological defects that can reduce the responsiveness to drug therapy, and the possible side effects related to nephrotoxicity when a renal involvement is already present. Furthermore, the Candida typing in DS children have been revealed to differ from healthy non-syndromic children, and the risk of drug resistance and/or the lack of responsiveness of oral candidiasis sustained by NAC species is another factor to consider. For the elderly and denture wearers, some authors have recently reported the efficacy and safety of the use of probiotics on prophylaxis and treatment of oral candidiasis [33]; further studies in this direction on children with DS or other diseases associated with the onset of oral candidiasis could represent a potentially valid alternative to conventional drug therapies.

Last, it was reported that the onset of oral candidiasis in DS children was more frequently associated with lip lesions; another key strategy to prevent this further occurrence, is to re-establish the integrity of the lips, via the use of hydrating and healing topical products, based on the content of vitamin E, hyaluronic acids and similar occurrences is to re-establish the integrity of the lips, via the use of hydrating and healing topical products, based on the content of vitamin E, hyaluronic acids, and similar.

\section{Conclusions}

The scarcity and heterogeneity of works reporting manifestations that affect the oral mucosa of children with DS reveals a gap in our knowledge that should be filled with larger and more detailed studies accompanied by changes in the clinical practice. Greater attention to inspection of the oral mucosae of children with DS and, in general, of all those with special needs, is necessary.

Several benefits would be derived, as follows:

1. Reduction of the risk of underestimating the presence of oral mucosal pseudo-lesions;

2. Enhancement of the clinician's ability to intercept early signs of fungal infections; and

3. Prevention of these infections and/or interruption of the vicious circle of recurrence in subjects in which systemic and local conditions can favor them.

The support of non-invasive adjunctive tools [34-36] and the involvement of paediatric dentists and oral pathologists in these processes is desirable, as these professionals are inclined to work on children and trained to identify in detail any anomaly of the oral mucosa, rather than the dental ones [37-39].

In conclusion, scientific investigation and a personalized approach could offer more appropriate information to parents/caregivers and specialists dealing with DS children, to 
intercept and define benignant conditions and to prevent recurrent candidiasis, the related repeated use of pharmacological therapies and the effects resulting from lip fissures.

Author Contributions: A.L. and R.S. (Rossella Santoro) conceived the ideas; A.R., F.L., M.C. and D.D.S. collected and analyzed the data; M.C., M.S. and F.D.V. led the writing; A.L., M.P. and R.S. (Rosario Serpico) supervised and reviewed the project. All authors have read and agreed to the published version of the manuscript.

Funding: This research received no external funding.

Institutional Review Board Statement: Not applicable.

Informed Consent Statement: Not applicable.

Data Availability Statement: Not applicable.

Acknowledgments: We would like to thank our librarian, Remo, for his precious support which made it possible for us to work continuously and efficiently for the realization of the manuscript.

Conflicts of Interest: The authors declare no conflict of interest.

\section{References}

1. El-Gilany, A.H.; Yahia, S.; Shoker, M.; El-Dahtory, F. Cytogenetic and comorbidity profile of Down syndrome in Mansoura University Children's Hospital, Egypt. Indian J. Hum. Genet. 2011, 17, 157-163. [CrossRef]

2. Asim, A.; Kumar, A.; Muthuswamy, S.; Jain, S.; Agarwal, S. Down syndrome: An insight of the disease. J. Biomed. Sci. 2015, $22,41$. [CrossRef] [PubMed]

3. Daneshpazhooh, M.; Nazemi, T.M.; Bigdeloo, L.; Yoosefi, M. Mucocutaneous findings in 100 children with Down syndrome. Pediatr. Derm. 2007, 24, 317-320. [CrossRef] [PubMed]

4. Shore, S.; Lightfoot, T.; Ansell, P. Oral disease in children with Down syndrome: Causes and prevention. Community Pract. 2010, 83, 18-21. [PubMed]

5. Moreau, M.; Benhaddou, S.; Dard, R.; Tolu, S.; Hamzé, R.; Vialard, F.; Movassat, J.; Janel, N. Metabolic diseases and Down syndrome: How are they linked together? Biomedicines 2021, 9, 221. [CrossRef]

6. Kaczorowska, N.; Kaczorowski, K.; Laskowska, J.; Mikulewicz, M. Down syndrome as a cause of abnormalities in the craniofacial region: A systematic literature review. Adv. Clin. Exp. Med. 2019, 28, 1587-1592. [CrossRef]

7. Moher, D.; Liberati, A.; Tetzlaff, J.; Altman, D.G. Preferred reporting items for systematic reviews and meta-analyses: The PRISMA statement. Int. J. Surg. 2010, 8, 336-341. [CrossRef]

8. Sterne, J.A.C.; Hernán, M.A.; Reeves, B.C.; Savović, J.; Berkman, N.D.; Henry, M.V.D.; Altman, D.G.; Ansari, M.T.; Boutron, I.; Carpenter, J.R.; et al. ROBINS-I: A tool for assessing risk of bias in non-randomised studies of interventions. BMJ 2016, 355, i4919. [CrossRef]

9. Ercis, M.; Balci, S.; Atakan, N. Dermatological manifestations of 71 Down syndrome children admitted to a clinical genetics unit. Clin. Genet. 1996, 50, 317-320. [PubMed]

10. Bilgili, S.G.; Akdeniz, N.; Karadag, A.S.; Akbayram, S.; Calka, O.; Ozkol, H.U. Mucocutaneous disorders in children with down syndrome: Case-controlled study. Genet. Couns. 2011, 22, 385-392.

11. Carlstedt, K.; Krekmanova, L.; Dahllöf, G.; Ericsson, B.; Braathen, G.; Modéer, T. Oral carriage of Candida species in children and adolescents with Down's syndrome. Int. J. Paediatr. Dent. 1996, 6, 95-100. [CrossRef]

12. Chow, K.M.; O'Donnell, D. Concomitant occurrence of hypodontia and supernumerary teeth in a patient with Down syndrome. Spec. Care Dent. 1997, 17, 54-57. [CrossRef] [PubMed]

13. Scully, C.; Van Bruggen, W.; Dios, P.D.; Casal, B.; Porter, S.; Davison, M.-F. Down syndrome: Lip lesions (angular stomatitis and fissures) and Candida albicans. Br. J. Derm. 2002, 147, 37-40. [CrossRef] [PubMed]

14. Camacho, F.M.; Mazuecos, J.; Ferrándiz, L.; Cantalejo, C.; Cabello, Á. Phenotypical and dermatological findings of Down syndrome in Southern Spain. Eur. J. Pediat. Derm. 2014, 24, 7-12.

15. Ribeiro, E.L.; Scroferneker, M.L.; Cavalhaes, M.S.; Campos, C.C.; Nagato, G.M.; Souza, N.A.; Ferreira, W.M.; Cardoso C., G.; Dias, S.M.S.; Pimenta, F.C.; et al. Phenotypic aspects of oral strains of Candida albicans in children with Down's syndrome. Braz. J. Biol. 2006, 66, 939-944. [CrossRef]

16. Maranhão, F.C.D.A.; Mendonça, N.M.; Teixeira, T.C.; Lages, G.A.D.C.S.; De Melo, J.A.; Porciuncula, C.G.G.; Filho, E.A.D.S.; Silva, D.M.W. Molecular Identification of Candida Species in the Oral Microbiota of Individuals with Down Syndrome: A Case-Control Study. Mycopathologia 2020, 185, 537-543.

17. Sureshbabu, R.; Kumari, R.; Ranugha, S.; Sathyamoorthy, R.; Udayashankar, C.; Oudeacoumar, P. Phenotypic and dermatological manifestations in Down Syndrome. Derm. Online J. 2011, 17, 3.

18. Shukla, D.; Bablani, D.; Chowdhry, A.; Thapar, R.; Gupta, P.; Mishra, S. Dentofacial and cranial changes in down syndrome. Osong Public Health Res. Perspect. 2014, 5, 339-344. [CrossRef] 
19. Areias, C.; Sampaio-Maia, B.; Pereira, M.D.L.; Azevedo, Álvaro; Melo, P.; Andrade, C.; Scully, C. Reduced salivary flow and colonization by mutans streptococci in children with Down syndrome. Clinics 2012, 67, 1007-1011. [CrossRef]

20. Al-Maweri, S.-A.; Tarakji, B.; Al-Sufyani, G.A.; Al-Shamiri, H.M.; Gazal, G. Lip and oral lesions in children with Down syndrome. A controlled study. J. Clin. Exp. Dent. 2015, 7, e284-e288. [CrossRef] [PubMed]

21. Szaflarska-Popławska, A.; Soroczyńska-Wrzyszcz, A.; Barg, E.; Józefczuk, J.; Korczowski, B.; Grzybowska-Chlebowczyk, U.; Więcek, S.; Cukrowska, B. Assessment of coeliac disease prevalence in patients with Down syndrome in Poland-A multi-centre study. Prz. Gastroenterol. 2016, 11, 41-46. [CrossRef]

22. Della Vella, F.; Lauritano, D.; Lajolo, C.; Lucchese, A.; Di Stasio, D.; Contaldo, M.; Serpico, R.; Petruzzi, M. The pseudolesions of the oral mucosa: Differential diagnosis and related systemic conditions. Appl. Sci. 2019, 9, 2412. [CrossRef]

23. della Vella, F.; Contaldo, M.; Fucile, R.; Panza, F.; Dibello, V.; Kalemaj, Z.; Ninivaggi, R.; Petruzzi, M.; Serpico, R. ORO-dental manifestations in West Syndrome. Curr. Top. Med. Chem. 2019, 19, 2824-2828. [CrossRef] [PubMed]

24. Romano, A.; Russo, D.; Contaldo, M.; Lauritano, D.; Della Vella, F.; Serpico, R.; Lucchese, A.; Di Stasio, D. Oral Manifestations in patients with glycogen storage disease: A systematic review of the literature. Appl. Sci. 2020, 10, 6720. [CrossRef]

25. Barillari, M.R.; Karali, M.; Di Iorio, V.; Contaldo, M.; Piccolo, V.; Esposito, M.; Costa, G.; Argenziano, G.; Serpico, R.; Carotenuto, M.; et al. Mild form of Zellweger Spectrum Disorders (ZSD) due to variants in PEX1: Detailed clinical investigation in a 9-years-old female. Mol. Genet. Metab. Rep. 2020, 24, 100615. [CrossRef] [PubMed]

26. Santoro, R.; Santoro, C.; Loffredo, F.; Romano, A.; Perrotta, S.; Serpico, R.; Lauritano, D.; Lucchese, A. Oral clinical manifestations of neurofibromatosis type 1 in children and adolescents. Appl. Sci. 2020, 10, 4687. [CrossRef]

27. De Benedittis, M.; Petruzzi, M.; Favia, G.; Serpico, R. Oro-dental manifestations in Hallopeau-Siemens-type recessive dystrophic epidermolysis bullosa. Clin. Exp. Derm. 2004, 29, 128-132. [CrossRef]

28. Barankin, B.; Guenther, L. Dermatological manifestations of Down's syndrome. J. Cutan. Med. Surg. 2001, 5, 289-293. [CrossRef]

29. CSupplement, D.; Contaldo, M.; Romano, A.; Mascitti, M.; Fiori, F.; della Vella, F.; Serpico, R.; Santarelli, A. Association between denture stomatitis, candida species and diabetic status. J. Biol. Regul. Homeost. Agents 2019, 33, 35-41.

30. Paoletti, I.; Fusco, A.; Grimaldi, E.; Perillo, L.; Coretti, L.; Di Domenico, M.; Cozza, V.; Lucchese, A.; Contaldo, M.; Serpico, R.; et al. Assessment of host defence mechanisms induced by Candida species. Int. J. Immunopathol. Pharm. 2013, 26, 663-672. [CrossRef] [PubMed]

31. Contaldo, M.; Lucchese, A.; Lajolo, C.; Rupe, C.; Di Stasio, D.; Romano, A.; Petruzzi, M.; Serpico, R. The oral microbiota changes in orthodontic patients and effects on oral health: An overview. J. Clin. Med. 2021, 10, 780. [CrossRef] [PubMed]

32. Groll, A.H.; Tragiannidis, A. Update on antifungal agents for paediatric patients. Clin. Microbiol. Infect. 2010, 16, 1343-1353. [CrossRef] [PubMed]

33. Hu, L.; Zhou, M.; Young, A.; Zhao, W.; Yan, Z. In vivo effectiveness and safety of probiotics on prophylaxis and treatment of oral candidiasis: A systematic review and meta-analysis. BMC Oral Health 2019, 19, 140. [CrossRef]

34. Contaldo, M.; Serpico, R.; Lucchese, A. In vivo imaging of enamel by reflectance confocal microscopy (RCM): Non-invasive analysis of dental surface. Odontology 2014, 102, 325-329. [CrossRef]

35. Contaldo, M.; Lucchese, A.; Gentile, E.; Zulli, C.; Petruzzi, M.; Lauritano, D.; Amato, M.R.; Esposito, P.; Riegler, G.; Serpico, R. Evaluation of the intraepithelial papillary capillary loops in benign and malignant oral lesions by in vivo virtual chromoendoscopic magnification: A preliminary study. J. Biol. Regul. Homeost. Agents 2017, 31, 11-22.

36. Contaldo, M.; Di Stasio, D.; della Vella, F.; Lauritano, D.; Serpico, R.; Santoro, R.; Lucchese, A. Real time in vivo confocal microscopic analysis of the enamel remineralization by casein phosphopeptide-amorphous calcium phosphate (CPP-ACP): A Clinical proof-of-concept study. Appl. Sci. 2020, 10, 4155. [CrossRef]

37. Contaldo, M.; Della Vella, F.; Raimondo, E.; Minervini, G.; Buljubasic, M.; Ogodescu, A.; Sinescu, C.; Serpico, R. Early Childhood Oral Health Impact Scale (ECOHIS): Literature review and Italian validation. Int. J. Dent. Hyg. 2020, 18, 396-402. [CrossRef]

38. Pastore, L.; de Benedittis, M.; Petruzzi, M.; Tatò, D.; Napoli, C.; Montagna, M.T.; Catassi, C.; Serpico, R. Importanza dei segni orali nella diagnosi di forme atipiche di malattia celiaca [Importance of oral signs in the diagnosis of atypical forms of celiac disease]. Recenti Prog. Med. 2004, 95, 482-490. [PubMed]

39. Petruzzi, M.; Lucchese, A.; Campus, G.; Crincoli, V.; Lauritano, D.; Baldoni, E. Oral stigmatic lesions of gastroesophageal reflux disease (GERD). Rev. Med. Chile 2012, 140, 915-918. [CrossRef] 